\title{
Cost-offset following specialist treatment of severe personality disorders
}

\author{
B. M. Dolan, F. M. Warren, D. Menzies and K. Norton
}

\begin{abstract}
Senvice usage of 24 patients with a personallty disorder was edchblithed for one yecr pre-treatiment and one yecr posttrectiment via a prospective survoy of the potients, their orfoind referrer and the's generel practilloner. The overage annuat cost of poychiatilic and prtion services (colculated from extra-contractual referrels (ECP) tarills and Home Ollice dota) was $\$ 13966$ pre-trectiment compared to $\$ 1303$ potthectiment, reprecentiling a cost-otset of $\$ 12658$ per pallent per year. The overage cout of the specially adinlecton wos 525641 . Thus the coet to the Nation for treating theees personcilly disordered potients in aferticry trectment resource would be recouped within two yeciss and represent a soving therecifier.
\end{abstract}

In some areas of psychotherapy there remains a paucity of adequate research into treatment outcome (Holmes, 1994; Marks, 1994). However, research evidence demonstrates good outcome of therapeutic community treatment for personality disordered patients in terms of psychiatric, psychological and behavioural changes (Dolan \& Coid, 1993). Indeed, the recent joint Department of Health/Home Office Committee on Services for Mentally Disordered Offenders (Reed, 1994) acknowledged that studies of therapeutic communities showed the most promising results of any form of treatment for psychopathic disorder (p. 16) and recommended that more such units be provided (p. 43).

In light of this it is surprising that the scepticism regarding the treatability of personality disordered patients remains and that speclalist psychotherapeutic treatments are often regarded as an expenstve luxury (Marks, 1994). In the climate of cost-awareness which now dominates the National Health Service (NHS), the onus is clearly on those services which can effect lasting improvement in their patients' psychological condition (i.e. beyond the period of actual treatment), to demonstrate the fact and to evaluate such treatment in financial terms.

Patients suffering with personality disorder place a high demand on health, as well as social and criminal justice, services which tend to be 'sucked in' in a reactive and unproductive way (Perry et al, 1987). One reason is that such patients typically fail to engage in or dertve benefit from therapy and the severity of the behavioural (often antisocial) component of their disorder means they may not be adequately and safely treated in out-patient settings, or even dayhospital facilities which do not provide continuous support and/or supervision. Many have long histories of repeated contacts with psychiatric, social, forensic, penal and probation services which, because they represent incomplete or inadequate treatments, do not confer lasting benefit; indeed many patients with personality disorders learn new aberrant coping strategles in such settings, including inappropriate dependence on professional carers.

Their antisocial and destructive behaviour often leads them to be seen as less deserving of health care service provision. This view may be especially prevalent when budgets are limited and the use of resources has to be closely monitored and rationalised. But refusing to fund treatment for such patients is a false economy, even if viewed solely in financial terms, since spontaneous remission of severe personality disorders is uncommon and untreated a patient will continue to remain a burden to professionals. In spite of this some purchasing Health Authoritles, in apparent ignorance of the existing high costs of treating this group of patients, do not believe that additional financial outlay (in the form of expert, tertiary level, in-patient resources) is costbeneficial. This may be because the actual financial costs of the service usage of personality disordered people have rarely been quantified. However, in an earlier study (Menzles et al, 1993) we showed that a single cohort of 29 personality disordered patients admitted to Henderson Hospital service used a total of $\$ 423115$ worth of psychiatric and prison services in the one year prior to their admission. We extrapolated from earlier descriptive research data which showed a $40 \%$ reduction in service usage post-treatment and suggested that the initial cost of specialist treatment would be outweighed by the projected cost offset from this reduction over the ensuing four years. 
Subsequently, we have had the opportunity to follow that same cohort of patients for one year following their discharge from treatment and have been able to calculate the actual service costs.

\section{The study}

The sample in the initial study was 29 consecutive admissions to Henderson Hospital (which has 29 beds) in May 1992. Data on mental health and forensic service usage in the one year prior to their admission to Henderson Hospital were collected retrospectively from case notes and survey questionnaires (Menzies et al, 1993).

One year after discharge from treatment a brief questionnaire was sent to the 29 patients their original referrers and their current general practitioners (GPs), asking for details of service usage since leaving Henderson Hospital. Information was returned from at least one professional source for 24 patients $(73 \%)$ who formed the follow-up sample. Data came from the referrer only in ten cases (42\%), the GP only in seven cases (29\%) and from both professionals in seven cases (29\%). In seven cases (29\%) service usage data were also supplied by the patient. There was no difference in the figures for service usage when the source of information was the referrer, the GP or both, however, two patients gave information about recetving private counselling which was not recorded by their referrer or GP.

Twenty-three of the 24 subjects had completed the personality diagnostic questionnaire (PDQ-R; Hyler \& Reider, 1987) on referral to Henderson Hospital. This is a self-report assessment of DSM-III-R personality disorder and thus susceptible to over-diagnosis. However, subjects showed multiple morbidity and met a mean of 6.04 (s.d.=2.25) PDQ-R personality disorder criteria each. The most prevalent PDQ-R diagnosis was borderline personality disorder in $74 \%$ of subjects.

Costs of psychiatric in-patient, out-patient and day-patient services were calculated from extracontractual referrals (ECR) tariffs provided by the four Thames Regional Health Authorities. Initial costs were calculated using 1992/93 tariffs and follow-up costs using 1993/94 tariffs.

\section{In-patient general psychiatry tariffs}

The average daily tariff for a general acute psychiatric in-patient bed across the Thames Reglons was $£ 153.20$ for $1992 / 3$ and $£ 179$ in 1993/4. The daily bed tariff for Henderson Hospital was reduced from $\$ 111$ to $£ 110$ in the same period.) The average daily bed cost of the Close Supervision Units in 1992/3 was $\$ 173$.

\section{Out-patient general psychiatry tariffs}

Two calculations of out-patient costs were made. If a patient reported only having seen a psychiatrist' we judged this, conservatively, to mean having been assessed and offering one appointment. The average cost of such treatment was $\$ 179$ in 1992/3 and $£ 244$ in 1973/4. If a patient reported having had 'individual therapy' of any type, but did not specify for how many sessions, we costed this using the figures for an assessment plus eight appointments. The average figure for a treatment package calculated in this was was $£ 586$ in 1992/33 and $£ 790$ in 1993/4. Day hospital costs were $£ 71$ and $£ 70$ per day respectively.

\section{Prison costs}

Prison costs were taken from the Home Office figures for 1991 (HMSO, 1991). The average cost of a week in a British adult prison was $\$ 386$ (range £238-744).

\section{Findings}

Table 1 presents a summary of mean psychiatric and prison service costs incurred by the 24 patients in the year prior to their admission. Costs in the year after admission are shown in Table 2.

\section{In-patient costs}

In the year prior to treatment 17 subjects $(81 \%)$ had been in-patients (for a total of 1568 days) compared with three (12.5\%) in the year following treatment (for a total of $\mathbf{7 3}$ days). One of these patients was readmitted to Henderson Hospital. Two patients (8\%) had also been in Close Supervision Units for a total of 140 days before admission; however, none of the 24 subjects had been held in a secure unit in the year following treatment. Thus, the cumulattve annual inpatient costs pre-treatment were $\$ 264438$ compared with £19 462 post-treatment.

\section{Out-patient costs}

Six (25\%) patients were reported as having had an out-patient assessment in the year before admission and two afterwards (8\%). Twelve (50\%) patients had out-patient treatment in the year before admission and the same number had outpatient treatment afterwards. Three residents (12.5\%) had attended a day hospital for a total of 404 days before treatment and one (4.1\%) had attended for 28 days at follow-up. The cumulative annual out-patient costs pre-treatment were $£ 36790$ compared with $£ 11928$ post-treatment.

\section{Prison costs}

Four (17\%) residents had been in custody in the previous year for a total of 88 weeks at a cost of $£ 33968$. None of the 24 patients were reported as being in custody in the year following treatment. 
Table 1. Psychlatric and penal service usage in the one-year prior to admission to Henderson Hospltal: 24 patients at 1992/3 tariffs

\begin{tabular}{|c|c|c|c|c|c|}
\hline Category & Units & $\begin{array}{l}\text { Pationts } \\
n\end{array}$ & $\begin{array}{l}\text { Unilts } \\
n\end{array}$ & $\begin{array}{l}\text { Unit mocen } \\
s\end{array}$ & $\begin{array}{l}\text { Total cot } \\
s\end{array}$ \\
\hline $\begin{array}{l}\text { In-patients beds } \\
\text { Secure poychlatilc beds }\end{array}$ & $\begin{array}{l}\text { Days } \\
\text { Days }\end{array}$ & $\begin{array}{r}17 \\
2\end{array}$ & $\begin{array}{r}1568 \\
140\end{array}$ & $\begin{array}{l}153.20 \\
173\end{array}$ & $\begin{array}{r}240218 \\
24220\end{array}$ \\
\hline Tolat in-pattient & & & & & 264438 \\
\hline $\begin{array}{l}\text { Out-patient assessments } \\
\text { Out-patient therapy } \\
\text { Day Hospltal }\end{array}$ & $\begin{array}{l}\text { Assessments } \\
\text { Eplsodes } \\
\text { Doys }\end{array}$ & $\begin{array}{r}6 \\
12 \\
3\end{array}$ & $\begin{array}{r}6 \\
12 \\
404\end{array}$ & $\begin{array}{r}179 \\
586 \\
71\end{array}$ & $\begin{array}{r}1074 \\
7032 \\
28684\end{array}$ \\
\hline Total out-potient & & & & & 36790 \\
\hline Pitson & Weok & 4 & 88 & 386 & 33968 \\
\hline Tolal coats & & & & & 335196 \\
\hline Coet per potient & & & & & 13966 \\
\hline
\end{tabular}

Table 2. Psychiatric and penal service usage in the one-year following admission to Henderson hospltal: 24 patients at 1993/4 tarlffs

\begin{tabular}{|c|c|c|c|c|c|}
\hline Cologory & Units & $\begin{array}{l}\text { Pationts } \\
n\end{array}$ & $\begin{array}{l}\text { Units } \\
n\end{array}$ & $\begin{array}{l}\text { Unit moen } \\
s\end{array}$ & $\begin{array}{l}\text { Tolat cont } \\
\text { S }\end{array}$ \\
\hline $\begin{array}{l}\text { In-patient beds } \\
\text { Henderson hospltal }\end{array}$ & $\begin{array}{l}\text { Days } \\
\text { Days }\end{array}$ & $\begin{array}{l}3 \\
1\end{array}$ & $\begin{array}{l}73 \\
50\end{array}$ & $\begin{array}{l}179 \\
110\end{array}$ & $\begin{array}{r}13962 \\
5500\end{array}$ \\
\hline Tolal In-patient & & & & & 19462 \\
\hline $\begin{array}{l}\text { Out-patient assessments } \\
\text { Out-patient therapy } \\
\text { Day hospltal }\end{array}$ & $\begin{array}{l}\text { Assessments } \\
\text { Eplsodes } \\
\text { Days }\end{array}$ & $\begin{array}{r}2 \\
12 \\
1\end{array}$ & $\begin{array}{r}2 \\
12 \\
28\end{array}$ & $\begin{array}{r}244 \\
790 \\
70\end{array}$ & $\begin{array}{l}488 \\
9480 \\
1960\end{array}$ \\
\hline Total out-potient & & & & & 11928 \\
\hline Tolal costs & & & & & 31390 \\
\hline Coet per patient & & & & & 1308 \\
\hline
\end{tabular}

Total cost offset

Overall the total annual costs of prison and psychiatric service usage by these 24 patients was reduced from $£ 335196$ ( $\$ 13966$ per person) In the year before treatment to $£ 31390$ ( $£ 1308$ per person) in the year following treatment. This represented a total cost-offset of $\$ 303806$ which is an average cost-offset of $\$ 12658$ per patient.

\section{Length of stay and cost of Henderson Hospital treatment}

The 24 residents were in treatment at Henderson Hospital for an average of 231 days (range $=1$ 365). The Henderson Hospital bed tariff at that time was fill per day, thus the average treatment episode of Henderson Hospital for this cohort cost £25 641 .

\section{Comment}

In accord with research on personality disordered patients in the USA (Perry et al, 1987), the 24 patients in this study had used a considerable amount of health and prison services in the year before admission at Henderson Hospital, at an estimated mean cost per patient of $\$ 13966$ (a total annual health care cost pre-treatment of \$335 196). Overall there was a major reduction in service usage for the 24 patients following specialist in-patient treatment, to $\$ 1308$ per patient, which represented an average cost-offset of $\$ 12658$. If this reduction in service usage is 
maintained then the initial cost of the admission to Henderson Hospital ( $\$ 25$ 641) would be recouped within just over two years and could be construed as a financial saving (to the Nation) thereafter. However, this saving may be no consolation to the individual purchasers given the current funding system. Any purchaser financially supporting a referral to Henderson Hospital (or another similarly funded tertiary service) will not 'save' money from their own budget, even when treatment is successful, since the cost of the existing local purchaser-provider contract will not be diminished because of what amounts to an additional extracontractual specialist referral. However, appropriate and successful tertiary treatment may at least obviate the need for a further call on the ECR budget in the following year. Supra-regional funding of tertiary level treatment centres, such as Henderson Hospital, would save those 'unfortunate' purchasers, who have patients with such special needs from the 'penalty' of supporting their tertiary referral or ECR. Such a funding mechanism might remove disincentives to refer, since it seems all too common that financial considerations trump clinical need (Dolan et al, 1994).

This study assesses costs using average figures dertved from data supplied by the four Thames Regional Health Authorities which provide only a rough guide to national charges, although $75 \%$ of Henderson Hospital patients come from those four regions. The use of retrospective case note information together with patients' and referrers' self-reports (for the first stage) and survey data from patient, referrer and GP (for the second stage) may have led to inaccuracies. In only $29 \%$ of cases was follow-up information verified by two professionals. However, the absence of any national (or even regional) system to identify hospital admissions of individuals makes cross checking for missing data impossible. The health care costs presented will be an underestimate of true costs since treatment via a GP or casualty department was not included. However, the under-representation of service use may equally influence the pre-treatment and follow-up figures, hence both will be underestimates of total costs involved that year. It is also possible that the year prior to admission to any tertiary treatment centre is not typical, the decision to refer a patient may reflect a worsening of their condition or a perception of an inappropriately high demand on local (secondary) services. As it cannot be simply assumed that each year will see the same level of demand on such services, further long-term research is required. This study measured only the health and penal service cost offset and did not attempt to measure cost-benefit which would have required a much fuller and more detailed financial profile, including past and future employment and tax payment status of patients.
We were unable to trace five (17\%) of our original sample of 29 patients. It is possible that those five patients had a worse outcome in terms of service usage than those we were able to follow up. If the patient returned to the original referring catchment area, it would be likely that a referrer or GP would be interested in communicating a poor outcome of tertlary service input when requested to do sol However, some patients move on to new territory after treatment for a variety of reasons, including the maintenance of a peripatetic lifestyle. In such instances referrers and GPs may have replied because they had lost contact and possibly felt relief that their patient was no longer in touch. Other 'poor outcomes' which may not have prevented contact with the original referrer could have been re-hospitalisation elsewhere, imprisonment or death (a recent audit study showed that three of a cohort of 128 untreated referrals had committed suicide and one was a victim of homicide within a year of unsuccessful referral to Henderson Hospital).

Despite these caveats the study demonstrates a significant reduction in overall service usage which is financially quantifiable. If the benefit also includes entry or re-entry into paid employment then there are additional financial implications and cost-benefits. However, in presenting this outcome data based on sterling, the psychological and social benefits to the patient and his or her family and friends should not be forgotten or minimised. There is additional research from Henderson Hospital which demonstrates the behavioural and psychological benefits of treatment (Copas et al, 1984; Dolan et al, 1992), many of which will not be readily or meaningfully translated in financial terms.

\section{References}

Dolan, B. \& Com, J. (1993) Psychopathic and Antt-social Personaltty Disorders: Treatment and Research Issues. London: Gaskell.

-. Evans, C. D. H. \& NORTON, K. (1994) Funding treatment for offender patients: do financial considerations trump clinical need? Joumal of Forenstc Psychtatry, 5, 263-272.

-. - \& WusON, J. (1992). Therapeutic community treatment for personality disordered adults: changes in neurotic symptomatology on follow-up. International Journal of Soctal Psychiatry. 38, 243-250.

HMSO (1991) Report on the Work of the Prison Service: Apri 1990-March 1991. Cm 1724. London: HMSO.

HoLmEs, J. (1994) Psychotherapy - A luxury the NHS can not afford? More expenstve not to treat? Brittsh Medical Journal, 309, 1070-1071.

HYLER, S. \& REIDER, R. O. (1987) Personality Dlagnostic Questionnatre-Revistted. New York: New York State Psychiatric Institute.

MARKS, I. (1994). Psychotherapy - A luxury the NHS can not afford? Unevaluated or ineffictent approaches are hard to justify. Brittsh Medical Joumal, so9. 1071-1072.

MenzIES, D., DOLAN, B. \& Norton, K. (1993) Are short term savings worth long term costs? Funding treatment for personality disorders. Psychiatric Bullettr, 17, 517-519. 
PerRy, J. C., LAvari, P. W. \& Hoke, L. (1987) A Markow model for predicting levels of psychiatric service use in borderline and anti-soctal personality disorders and bipolar type II affective disorder. Joumal of Psychiatric Research, 21, 213-232.

REED, J. (1994) A Revilew of Services for Mentally Disordered Offenders and Others with Similar Needs: Report of the Sub-Committee on Psychopathic Disorder. Department of Health/Home Office.

*B. M. Dolan, Research Fellow and Hon. Lecturer in Forensic Psychiatry; F. M. Warren, Psychology
Research Assistant, D. Menzies, Senior Registrar in Psychotherapy; and K. Norton, Consultant Psychotherapist and Hon. Senior Lecturer, Henderson Hospital, 2 Homeland Drive, Sutton, Surrey, SM2 5LT, and St. George's Hospital Medical School, Section of Forensic Psychiatry, Tooting, London, SW17 ORE

*Correspondence: Dr Bridget Dolan, Henderson Hospital, Sutton, Surrey SM2 5LT

\section{Caring for a Community}

\section{The Community Care Policy of the Royal College of Psychiatrists}

\section{by Dinesh Bhugra, Keith Bridges and Chris Thompson}

This report presents some examples of philosophy, approaches, good practices, and service aspirations found in the UK. Some of these services have resulted from Government policy and research into specific psychiatric disorders while others have drawn upon developments abroad. Many services, however, have developed based on clinical experiences, pragmatism, a sensitivity to local needs, collaborative approaches involving a variety of local organisations, and the desire of practitioners to have available to the public an effective range of services. The report describes actual and potential community services providing for the mental health needs of the severely mentally ill.

\section{£10.00 90pp. • $1995 \bullet$ ISBN 090224177 X}

Available from bookshops and from the Publications Department, Royal College of Psychiatrists, 17 Belgrave Square, London SW1X 8PG (Tel. 0171-235 2351 extension 146) 